\title{
Influence of production factors on feed intake and feed conversion ratio of grow-finishing pigs
}

\section{Influência dos fatores de produção sobre o consumo de ração e a conversão alimentar de suínos em crescimento e terminação}

\author{
Caio Abércio da Silva ${ }^{1 *}$; Aliny Ketilim Novais²; Rita de Kássia Silva dos Santos²; \\ Carlos Rodolfo Pierozan ${ }^{2}$; Piero da Silva Agostini ${ }^{3}$; Josep Gasa Gasó ${ }^{4}$
}

\begin{abstract}
The aim of this study was to identify and quantify, through mathematical models, the production factors of grow-finishing (GF) phases that influence the daily feed intake (DFI) and feed conversion ratio (FCR) in pigs. Sixty-five GF farms were evaluated between 2010 and 2013, linked to a cooperative system located in the western Parana State, Brazil, representing 463 batches, with a mean of $642.79 \pm 363.29$ animals per batch, equalling approximately 300,000 animals. Forty production factors were considered that related to management, sanitation, installations and equipment, nutrition, genetics and environment on the farms. The DFI was influenced by the barn's position relative to the sun ( $\mathrm{P}=0.048)$, initial body weight $(\mathrm{P}<0.0001)$ and final body weight $(\mathrm{P}<0.0001)$. It was observed that the FCR was influenced by the barn's position relative to the sun $(\mathrm{P}=0.0001)$, the use of humidifiers/misting $(\mathrm{P}=0.03)$, the presence of composters $(\mathrm{P}=0.006)$, trees on the sides of barns $(\mathrm{P}<0.045)$, the initial body weight of the pigs $(\mathrm{P}<0.0001)$ and duration of the grow-finishing phase $(\mathrm{P}<0.0001)$. The variables selected in the models explained approximately 44 and $20 \%$ of the total variance in the DFI and FCR, respectively, demonstrating that this resource is a good tool for interpreting the factors related to the parameters evaluated.
\end{abstract}

Key words: Management. Multilevel modelling. Swine.

\section{Resumo}

Objetivou-se neste estudo identificar e quantificar, através de modelos matemáticos, os fatores de produção presentes em unidades de crescimento e terminação (CT) de suínos que influenciam os parâmetros consumo diário de ração (CDR) e conversão alimentar (CA). Foram avaliados o histórico produtivo de 65 granjas de CT entre os anos de 2010 e 2013, vinculadas a um sistema cooperativo localizado na região oeste do Estado do Paraná, Brasil, representando 463 lotes com média de 642,79 $\pm 363,29$ animais por lote, totalizando aproximadamente 300.000 animais. Foram considerados 40 fatores de produção relacionados ao manejo, sanidade, instalações e equipamentos, nutrição, genética e ambiente. Observou-se que o CDR foi influenciado pela posição dos barracões em relação ao sol $(\mathrm{P}=0,048)$, pelo peso de entrada $(\mathrm{P}<$ $0,0001)$ e de saída $(\mathrm{P}<0,0001)$. Para a variável $C A$ a posição dos barracões em relação ao sol $(\mathrm{P}=0,0001)$, o uso de umidificadores/nebulizadores $(\mathrm{P}=0,03)$, a presença de composteira $(\mathrm{P}=0,006)$ e de árvores nas laterais dos barracões $(\mathrm{P}=0,045)$, o peso de entrada $(\mathrm{P}<0,0001)$ e a duração da fase de $\mathrm{CT}(\mathrm{P}<$ $0,0001)$ influenciaram o parâmetro. As variáveis selecionadas nos modelos explicaram aproximadamente 44 e $20 \%$ da variância total do CDR e CA, respectivamente, sendo este recurso uma boa ferramenta para interpretar os fatores relacionados com os parâmetros avaliados.

Palavras-chave: Manejo. Modelagem multinível. Suínos.

\footnotetext{
${ }^{1}$ Prof. Dr., Departamento de Zootecnia, Universidade Estadual de Londrina, UEL, Londrina, PR, Brasil. E-mail: casilva@uel.br

2 Pesquisadores, UEL, Londrina, PR, Brasil.E-mail: alinyketilim@gmail.com; rita.zoo@live.com; carlospierozan@hotmail.com

${ }^{3}$ Pesquisador, Universidad Autonoma de Barcelona, UAB, Cerdanyola del Valles Catalunha, Espanha. E-mail: pieroagostini@ hotmail.com

${ }^{4}$ Prof., Universidad Autonoma de Barcelona, UAB, Cerdanyola del Valles Catalunha, Espanha. E-mail: josepgasa@uab.cat

* Author for correspondence
} 


\section{Introduction}

In Brazilian pig production, the growing and finishing (GF) phases are predominantly managed by pig farmers linked to cooperatives and private integrations (DAGA et al., 2008), accounting for over $80 \%$ of the total (ABCS, 2015). Despite the high concentration of producers linked to these complexes, GF farms hold management and nutrition and health programmes to little uniformity and usually have facilities and equipment with different characteristics (MAES et al., 2004; OLIVEIRA et al., 2007). Consequently, these conditions may contribute to the differences in growth performance of animals between farms.

Information about the impact of these factors on performance characteristics is scarce because few studies approach this issue (AGOSTINI et al., 2014). Less is known about the effects of the interaction between various factors that may influence feed efficiency in pigs (DOUGLAS et al., 2015). According to Heck (2009), it is important to have the domain and to act assertively in the main factors that influence the development of pigs in the growing and finishing phases for these steps to achieve high production costs (VAN HEUGTEN, 2010).

Mathematical models represented a tool that could help to understand and quantify the biological phenomena or factors involved in animal production (POMAR, 2014). This procedure could improve animal performance, the cost of production and provide an efficient utilization of feed according to each specific situation (TEDESCHI et al., 2005). This resource allows a joint assessment of the effects of one or more factors of production on a particular livestock parameter (VILLALBA MATA, 2000), which provides knowledge about the operation as a whole (GIBON et al., 1999), in contrast to experimental studies in which only a small number of factors are considered, which contributes to limitations in knowing what factors affect the efficiency in the systems of GF pigs (DOUGLAS et al., 2015). However, the use of mathematical models can support decisions regarding demand in production systems with limited information (data used in the model), which is a normal scenario on a farm (TEDESCHI et al., 2005).

Although there is evidence of the feasibility of this approach to allow an holistic view of GF farms in Brazil, this approach was recently applied and evaluated, involving over 93 farms with 683 batches and approximately 495,000 animals (PIEROZAN et al., 2016). The factors that most influenced the daily feed intake and feed conversion in GF units were the number of pigs per pen, the feeder model and the origin and sex of animals submitted for fattening. However, it is important to consider that the information obtained is not similar between companies or regions, and also, they underwent changes with the development of this activity. Furthermore, they were able to expose the factors that have an effect on performance.

Therefore, the objective of this study was to identify and quantify, using mathematical models, the impact of intrinsic and extrinsic factors of production present in GF farms linked to a cooperative system of the Western region of Paraná State, Brazil, on the parameters of daily feed intake and feed conversion. These factors display other critical points involved in predicting production rates and increases the perception of the most important factors that influence the performance of GF units.

\section{Materials and Methods}

The production history of 463 batches of pigs in GF phases $(642.79 \pm 363.29$ animals per batch) (mean \pm standard deviation), totalling approximately 300,000 animals from 65 GF farms linked to a cooperative system located in the Western region of the Paraná State (Brazil), were evaluated between 2010 and 2013. The batches of pigs in the nursery output weighed $21.72 \pm 1.31 \mathrm{~kg}$ and were kept in the GF phases until they achieved a slaughter weight of $113.28 \pm 4.26 \mathrm{~kg}$. 
The work model followed the methods by Agostini et al. (2014) in three stages. The first was the choice of the variables of livestock interest, which is the most important production factor in the cooperative complex (Tables 1 and 2). Subsequently, a procedure that offered reliability, agility and efficiency in collecting the information was established. More details on the first two steps are described in the following paragraphs. The third stage involved the development of a system that would ensure the representativeness of the data collected in the cooperative. To ensure representation, information from all of the farms belonging to the cooperative was collected. Furthermore, as opposed to Agostini et al. (2014), data were collected in the present study from a larger number of batches per farm (approximately 7.12 batches per farm).

The variables were selected from recent scientific studies. The experiences of the proposing team and of the cooperative's staff were divided into two groups: "dependent" and "independent" variables. The "dependent" variables corresponded to continuous variables, such as daily feed intake (DFI) and feed conversion (FC). The total feed intake per animal was calculated as the total amount of feed (in kilograms) delivered to each batch during the GF period, minus the amount of feed (in kilograms) remained in the silos when the animals were sent to slaughter, the result of which was divided by the number of pigs marketed. The DFI per animal was calculated using the results of total consumption per animal, divided by the average number of days in which the animals remained in the GF unit. The FC was obtained by dividing the total feed intake of each batch by the difference between the total kilograms of pigs sent to slaughter and the total kilograms of pigs that entered at the GF batch.
The "independent" variables evaluated included three continuous variables: initial weight, final weight and duration of GF phases. The initial weight corresponded to the average live weight of pigs when entering the farm, in GF units, and the final weight and the average live weight at slaughter were both expressed in kilograms. The duration of the GF phases represented the period, in days, that the animals remained in the GF unit.

Forty "independent" categorical variables were evaluated (Table 1), accounting for the factors of production, including issues linked to facilities, health status of the herd and aspects related to the nutritional, feed and animal managements.

An Excel spreadsheet was used as the basis for carrying out statistical analyses of the data collected, which were divided into two phases: exploratory analysis and models development. In the exploratory analysis phase, the data were submitted to a descriptive analysis of categorical variables performed through a frequency study using the SAS FREQ procedure (SAS Inst., Inc., Cary, NC, USA, version 9.2) (Table 1). The descriptive analysis of continuous variables was performed using measures of central tendency (mean and median) and dispersion (standard deviation, quartiles and amplitude) through the SAS MEANS procedure (Table 2). Continuous variables were submitted to statistical evaluations to assess the normality of their distributions through the SAS UNIVARIATE procedure. For the analysis of all the variables, the batch was considered the experimental unit, defined as the group of piglets that were coming out of the nursery phase and entering the GF unit, being held to slaughter. All batches were managed as all-in allout system. 
Table 1. Occurrence percentages in each category for the production factors (independent categorical variables) studied in 463 batches of growing and grow-finishing pigs.

\begin{tabular}{|c|c|}
\hline Variable & Percentage of batches $(\%)$ in each category \\
\hline Reform of facilities from $2009^{1}$ & Yes $(52.58 \%) ;$ no $(47.42 \%)$ \\
\hline Presence of shallow pools in pens ${ }^{1}$ & Yes (44.72); no (55.28\%) \\
\hline Humidifiers/misting in farm² & Yes (35.21\%); no (64.79\%) \\
\hline Presence of composters in farm ${ }^{2}$ & Yes $(86.18 \%)$; no $(13.82 \%)$ \\
\hline Trees around the barns of pigs ${ }^{2}$ & Yes $(73.00 \%)$; no $(27.00 \%)$ \\
\hline Barn's position relative to the $\operatorname{sun}^{3}$ & Opposite $(36.29 \%)$; parallel $(63.71 \%)$ \\
\hline Semester of pig placement on the farm ${ }^{4}$ & Summer/autumn (49.12\%); winter/spring (50.88\%) \\
\hline Number of animals placed ${ }^{4}$ & $<500(30.02 \%) ; 500-1,000(36.29 \%) ;>1,000(33.69 \%)$ \\
\hline Number of barns in the farm ${ }^{4}$ & One $(28.08 \%)$; two or more $(71.92 \%)$ \\
\hline Stall age ${ }^{4}$ & $<10$ years $(68.94 \%) ;>10$ years $(31.06 \%)$ \\
\hline Type of feeder ${ }^{4}$ & Linear dump (58.75\%); others (41.25\%) \\
\hline Presence of slurry tank ${ }^{4}$ & Yes $(57.45 \%)$; no $(42.55 \%)$ \\
\hline Labor force in the farm ${ }^{4}$ & Unfamiliar (13.61\%); familiar (86.39\%) \\
\hline Number of pigs per pen ${ }^{5}$ & $<20(95.82 \%) ; 20-40(2.86 \%) ;>40(1.32 \%)$ \\
\hline Building material/barns ${ }^{5}$ & Masonry (97.19\%); wood (1.73\%); mixed (1.08\%) \\
\hline Type of drinker ${ }^{5}$ & Nipple (98.06\%); water cup (1.94\%) \\
\hline Water source provided to animals ${ }^{5}$ & Well/headwater $(64.60 \%)$; treated water $(35.40 \%)$ \\
\hline Type of material for the roofs of the barns ${ }^{5}$ & Clay $(55.76 \%)$; others $(44.24 \%)$ \\
\hline Type of material for the water pipes ${ }^{5}$ & PVC pipe (91.41\%); hose (7.32\%); mixed (1.27\%) \\
\hline Type of floor material of the pens ${ }^{5}$ & Concrete $(100 \%)$ \\
\hline Electricity supply to the barns ${ }^{5}$ & Yes $(100 \%)$ \\
\hline Presence of waste lagoons in the farm ${ }^{5}$ & Yes $(100 \%)$ \\
\hline Presence of ventilation fans in the barns ${ }^{5}$ & No $(100 \%)$ \\
\hline Presence of exhaust fans in the barns ${ }^{5}$ & No $(100 \%)$ \\
\hline Agricultural areas close to the farm ${ }^{5}$ & Yes $(73.43 \%)$; no $(26.57 \%)$ \\
\hline Number of feed uses per period ${ }^{5}$ & Four $(92.22 \%)$; five $(7.78 \%)$ \\
\hline Different feeds according to the sex ${ }^{5}$ & No $(100 \%)$ \\
\hline Feed form ${ }^{5}$ & Pelleted $(100 \%)$ \\
\hline Use of shock with antibiotics management ${ }^{5}$ & Yes $(100 \%)$ \\
\hline Routes used to administer antibiotics ${ }^{5}$ & Water and feed $(100 \%)$ \\
\hline Programmes used in the farm ${ }^{5}$ & Ractopamine and immunocastration (100\%) \\
\hline Number of employed genetic ${ }^{5}$ & Three $(100 \%)$ \\
\hline Animal breeds used ${ }^{5}$ & Hybrids: Pietrain/Landrace/Large White (100\%) \\
\hline Baths housed in the farm are sexed ${ }^{5}$ & No $(100 \%)$ \\
\hline Sex segregation in pens ${ }^{5}$ & No $(100 \%)$ \\
\hline Location of animal origin ${ }^{5}$ & SPU $^{6}(68.77 \%)$; farrow-to-finish units $(31.23 \%)$ \\
\hline Sex of animals housed ${ }^{5}$ & Mixed $(100 \%)$ \\
\hline Enzootic pneumonia, Glasser's disease ${ }^{5}$ & Yes $(100 \%)$ \\
\hline Ileitis, meningitis, erysipela ${ }^{5}$ & Yes $(100 \%)$ \\
\hline
\end{tabular}

${ }^{1}$ Variables included only in the final regression model for dependent variable daily feed intake (DFI); ${ }^{2}$ Variables included only in the final regression model for dependent variable feed conversion (FC); ${ }^{3}$ Variables included in the final regression model for two dependent variables (DFI e FC); ${ }^{4}$ Variables initially considered for statistical analysis but not included in the final models; ${ }^{5}$ Variables rejected for statistical analysis due to low variability between categories; ${ }^{6}$ Specialized piglet production unit. 
Table 2. Measures of central tendency and dispersion for the dependent and independent continuous variables selected for the final models.

\begin{tabular}{lcccccccc}
\hline \multicolumn{1}{c}{ Variable } & $\mathrm{N}^{\mathrm{o}}$ of batches & Mean & $\mathrm{SD}$ & Minimum & $1^{\text {st }}$ quartile & Median & $3^{\text {rd }}$ quartile & Maximum \\
\hline Initial weight $(\mathrm{kg})$ & 463 & 21.72 & 1.31 & 15.01 & 21.43 & 21.94 & 22.38 & 24.65 \\
Final weight $(\mathrm{kg})$ & 463 & 113.28 & 4.26 & 96.03 & 110.28 & 113.04 & 115.90 & 126.09 \\
DGF (day) & 463 & 109.60 & 3.48 & 100.00 & 107.00 & 110.00 & 112.00 & 119.00 \\
DFI $\left(\mathrm{kg} \mathrm{pig}^{-1}\right)$ & 463 & 2.11 & 0.10 & 1.84 & 2.04 & 2.11 & 2.17 & 2.46 \\
FC $\left(\mathrm{kg} \mathrm{kg}^{-1}\right)$ & 463 & 2.52 & 0.08 & 2.28 & 2.47 & 2.52 & 2.57 & 2.78 \\
\hline
\end{tabular}

$\mathrm{SD}=$ standard deviation; $\mathrm{DGF}=$ duration of growing-finishing phases; $\mathrm{DFI}=$ daily feed intake; $\mathrm{FC}=$ feed conversion.

The models were fitted based on the variables coded in the first phase by mixed linear regression using the SAS MIXED procedure with the effect of the farm (primary) and batch linked to the farm considered as random factors, using the restricted maximum likelihood method (REML) for the estimation of variance components. The comparison of the goodness of fit of the final model was based on the proportion of variance explained by the different models, using the coefficient of determination (R2) as a parameter.

Initially, in the second phase, a single regression model was used for each variable as a fixed effect for each single dependent variable. The independent variables with $\mathrm{P} \leq 0.20$ were selected for the multivariate analysis.

Pearson and Spearman correlations were performed between the independent variables in the multivariate model to avoid multicollinearity between continuous variables and confounding problems between categorical variables. When two variables had a high correlation coefficient (absolute value $\geq 0.60$ ), only one was used in the multivariate analysis. The choice between them was made by comparing the $\mathrm{P}$ values in the univariate analysis, and additionally evaluating their biological relevance with respect to the dependent variable. Subsequently, all independent variables selected in the univariate analysis were submitted to the procedure "stepwise", where all the factors with $\mathrm{P}<0.05$ were kept in the final multivariate model. Fixed-effect testing was based on the F-test with denominator degrees of freedom approximated by the Satterthwaite's procedure. Significant interactions $(\mathrm{P}<0.05)$ between the variables in the multivariate model were tested and included.

After obtaining the models for each dependent variable, the residues were plotted against the predicted values to check the homogeneity of variances and the presence of outliers. All of the factors with $\mathrm{P}<0.05$ in the final models for each of the two dependent variables (DFI and FC) were considered statistically significant.

\section{Results}

Table 1 shows the percentages of the occurrence of independent categorical variables (factors of production) studied in GF farms. The factors that were initially considered for statistical analysis and later added in the multiple linear regression model for the dependent variable, DFI, were "reform of facilities from 2009" and "presence of shallow pools in pens". The factors added into the multiple linear regression model for the dependent variable, FC, were "humidifiers/misting in farm", "presence of composters in farm" and "trees around the barns of pigs". The factor, "barn's position relative to the sun," was subjected to the initial statistical analysis and was added in two models, for DFI and FC.

The DFI per pig was $2.11 \pm 0.10 \mathrm{~kg}$ (mean \pm standard deviation) (range 1.84 to $2.46 \mathrm{~kg}$ ) (Table 2). Multiple linear regression analysis indicated that the DFI was influenced by the barn's position relative to the sun $(\mathrm{P}=0.048)$, initial weight $(\mathrm{P}<0.0001)$ and final weight $(\mathrm{P}<0.0001)$ (Table 3$)$. 
When the barn's position on the farm was contrary relative to the sun, the DFI of pigs increased approximately $0.9 \%$ (Table 3 ). For each additional kilogram of initial weight in animals, the DFI increased by 16 grams (relative to average), and for each kilogram of final weight, DFI increased by 13 grams.

The variance of the model without predictors (null model) and for the model with predictors (full model) for the DFI are shown in Table 4. The total variance in the DFI null model was 0.00993 , where
$0.00144(14.5 \%)$ was observed between farms and 0.00849 (85.5\%), was observed between batches linked to a farm. After the variables were included in the multivariate model, the variance for the DFI was reduced to 0.00552 , which indicated that approximately $44.4 \%$ of the total variance related to the DFI was explained by the variables included in the full model. The percentages of variance that were elucidated between farms and between batches linked to a farm using the full model for DFI were 52.3 and $43.0 \%$, respectively.

Table 3. Multiple linear regression model to estimate the effects of production factors on the daily feed intake (DFI) in 463 batches.

\begin{tabular}{lccccc}
\hline \multicolumn{1}{c}{ Factors } & \multirow{2}{*}{ Category } & Estimate (s.e.) & \multicolumn{3}{c}{ 95\% CL } \\
\cline { 5 - 6 } & & & Low & Upper & P-value \\
\hline Intercept & --- & $0.234(0.105)$ & 0.028 & 0.439 & 0.02 \\
Reform of facilities from 2009 & Yes & $0.014(0.009)$ & -0.005 & 0.033 & 0.16 \\
& No & 0 & --- & --- & --- \\
Presence of shallow pools in pens & Yes & $0.013(0.009)$ & -0.006 & 0.033 & 0.18 \\
& No & 0 & --- & --- & --- \\
Barn's position relative to the sun & Opposite & $0.018(0.009)$ & 0.000 & 0.037 & 0.048 \\
Initial weight & Parallel & 0 & --- & --- & --- \\
Final weight & --- & $0.016(0.003)$ & 0.009 & 0.021 & $<0.0001$ \\
\hline
\end{tabular}

s.e. $=$ standard error; $\mathrm{CL}=$ confidence level.

Table 4. Variance observed between farms and between batches within farms and percentage of variance explained by the variables included in the full model for daily feed intake (DFI).

\begin{tabular}{lccc}
\hline \multirow{2}{*}{ Effect } & \multicolumn{2}{c}{ Variance observed } & \multirow{2}{*}{ Variance explained } \\
\cline { 2 - 3 } & Null model $^{1}$ & Full model $^{2}$ & $52.32 \%$ \\
Farm & $0.00144(14.50 \%)$ & $0.00068(12.43 \%)$ & $43.00 \%$ \\
Batch (Farm) & $0.00849(85.50 \%)$ & $0.00484(87.57 \%)$ & $44.36 \%$ \\
Total & $0.00993(100 \%)$ & $0.00552(100 \%)$ & \\
\hline
\end{tabular}

${ }^{1}$ Model without predictors; ${ }^{2}$ Final model, with predictors.

The FC per pig/batch was $2.52 \mathrm{~kg} \pm 0.08$ (range 2.28 to $2.78 \mathrm{~kg}$ ) (Table 2). Multiple linear regression analysis showed that the FC was influenced by humidifiers/misting in the farm $(\mathrm{P}=0.03)$, the presence of composters at the farm $(\mathrm{P}=0.006)$, trees around the barns $(\mathrm{P}=0.045)$, the barn's position relative to the sun $(\mathrm{P}=0.0001)$, initial weight $(\mathrm{P}<0.0001)$ and duration of GF phases $(\mathrm{P}<0.0001)$ (Table 5).

When the farms had humidifiers/misting in their barns, the FC improved approximately $0.7 \%$ (Table $5)$. The animals from pig farms with a composter 
facility had an FC that was $1.2 \%$ better than the animals from farms that did not have this feature. The pigs housed on farms with trees planted around the barns had an FC that was $0.7 \%$ better than those on farms without trees. The FC was $1.2 \%$ worse for the animals kept in farms with barns built in the opposite direction of sunrise-sunset. For each additional kilogram of initial weight for the animals that arrived on the GF farm, the FC worsened by 0.022 units (relative to average), and for each additional day that the animals remained on the GF period, the FC declined by 0.005 units.

Table 5. Multiple linear regression model to estimate the effects of production factors on the feed conversion (FC) in 463 batches.

\begin{tabular}{|c|c|c|c|c|c|}
\hline \multirow{2}{*}{ Factors } & \multirow{2}{*}{ Category } & \multirow{2}{*}{ Estimate (s.p.) } & \multicolumn{3}{|c|}{$95 \% \mathrm{CL}$} \\
\hline & & & Low & Upper & P-value \\
\hline Intercept & --- & $1.531(0.133)$ & 1.269 & 1.792 & $<0.0001$ \\
\hline \multirow{2}{*}{ Humidifiers/misting in farm } & Yes & $-0.017(0.008)$ & -0.032 & -0.002 & 0.03 \\
\hline & No & 0 & --- & --- & --- \\
\hline \multirow{2}{*}{ Presence of composters in farm } & Yes & $-0.029(0.010)$ & -0.049 & -0.008 & 0.006 \\
\hline & No & 0 & --- & --- & --- \\
\hline \multirow{2}{*}{ Trees around the barns of pigs } & Yes & $-0.017(0.008)$ & -0.034 & -0.000 & 0.045 \\
\hline & No & 0 & --- & --- & --- \\
\hline \multirow{2}{*}{ Barn's position relative to the sun } & Opposite & $0.030(0.008)$ & 0.015 & 0.045 & 0.0001 \\
\hline & Parallel & 0 & --- & --- & --- \\
\hline Initial weight & --- & $0.022(0.003)$ & 0.017 & 0.027 & $<0.0001$ \\
\hline Duration of GF phases & --- & $0.005(0.001)$ & 0.003 & 0.007 & $<0.0001$ \\
\hline
\end{tabular}

s.e. $=$ standard error; $\mathrm{CL}=$ confidence level; $\mathrm{GF}=$ growing and finishing.

The model without predictors (null model) for FC had a total variance of 0.00602 , where 0.00050 $(8.32 \%)$ was observed between farms, and 0.00552 (91.68\%) was observed between batches linked to the farm (Table 6). Once the variables were included in the multivariate model, the variance of
FC was reduced to 0.00482 , which indicated that approximately $19.9 \%$ of the total variance related to FC was explained by the variables selected for the full model. The percentage of variance between farms and batches linked to a farm, using the full model for FC, was 38.1 and $18.2 \%$, respectively.

Table 6. Variance observed between farms and between batches within farms and the percentage of variance explained by the variables included in the full model for feed conversion (FC).

\begin{tabular}{|c|c|c|c|}
\hline \multirow{2}{*}{ Effect } & \multicolumn{2}{|c|}{ Variance observed } & \multirow{2}{*}{ Variance explained } \\
\hline & Null model $^{1}$ & Full model $^{2}$ & \\
\hline Farm & $0.00050(8.32 \%)$ & $0.00031(6.42 \%)$ & $38.12 \%$ \\
\hline Batch (Farm) & $0.00552(91.68 \%)$ & $0.00451(93.58 \%)$ & $18.23 \%$ \\
\hline Total & $0.00602(100 \%)$ & $0.00482(100 \%)$ & $19.88 \%$ \\
\hline
\end{tabular}

${ }^{1}$ Model without predictors; ${ }^{2}$ Final model, with predictors. 


\section{Discussion}

It was observed that the variables DFI $(\mathrm{P}=0.048)$ and $\mathrm{FC}(\mathrm{P}=0.0001)$ (Tables 3 and 5) were affected by the barn's position relative to the sun, increasing the DFI and decreasing the FC of animals housed in barns positioned crosswise relative to sunrisesunset. When the barn was built in this direction, there was direct sunlight on the sides of the barn for the majority of the day. This could have increased the temperature inside of the barn, causing a negative effect on animal performance. The decrease in the DFI is the most effective mechanism to reduce heat stress (COLLIN et al., 2001) and appears to be essential in regulating the body temperature of pigs (RENAUDEAU et al., 2011). Through this strategy, the resulting heat production of digestive and metabolic processes related to food intake was minimized (MANNO et al., 2006). However, there was an increase in DFI for housed pigs, which could have been related to the environment where consumption should decrease. There is a possibility that other unmeasured factors may have affected the results, such as the formulation of feed. The decline in FC coincided with the results from an earlier study by Kiefer et al. (2009), who observed that this parameter declined in pigs between 30 and $60 \mathrm{~kg}$ maintained in the heat compared to pigs in a thermoneutral environment. Renaudeau et al. (2011) reported a worsening of $0.2 \mathrm{~kg} \mathrm{~kg}^{-1}$ in the $\mathrm{FC}$ of pigs weighing $50 \mathrm{~kg}$ at a temperature $36{ }^{\circ} \mathrm{C}$ compared to pigs maintained at $30^{\circ} \mathrm{C}$.

The factor of humidifiers/misting contributed to an improvement of the $\mathrm{FC}$ in animals $(\mathrm{P}=0.03)$ (Table 5). Growing pigs produced a larger quantity of heat because of a high metabolic rate. Moreover, pigs in the GF phase have a difficulty in expelling heat because of an increase in the fat layer. This contributes to heat stress, resulting in energy consumed intended to control homeothermy with consequent worsening of the livestock performance index (NÄÄS; JUSTINO, 2014). The management of the environment on pig farms needs to ensure that the concentration of pollutants are minimized and the thermal environment is optimized to maximize production efficiency (BANHAZI et al., 2008). This objective can be achieve through misting, which allows evaporative cooling and is considered the most efficient system for air cooling (NÄÄS; JUSTINO, 2014). The results of this study were related to findings of Choi et al. (2010), who showed the importance of environmental control through ventilation/misting installations for pigs by comparing automatic with manual ventilation systems. Berton et al. (2015) also observed a worsening $\mathrm{FC}(\mathrm{P}<0.05)$ for animals in the GF phase that were subjected to climatic variations (uncontrolled environment). The results reinforce the importance of a system for controlling the thermal sensation of animals, improving thermal comfort and performance.

Regarding the factor of trees around the barns of pigs, this factor is associated with environmental benefits. The best $\mathrm{FC}$ results $(\mathrm{P}<0.045)$ were in favour of farms that adopted wooden sides (Table 5). Studies demonstrated a direct relationship between the FC pigs that were not found; however, the planting of trees on the sides of the barn reduces the direct impact of solar radiation on animals (DIAS et al., 2011), while minimizing the temperature inside the barns on hot days. Keeping animals in conditions within their thermoneutral zone maximizes performance (MILLER, 2012).

Another factor with a positive response on the FC was the use of composting on the farm $(\mathrm{P}=$ 0.006) (Table 5). An animal carcass is a great source of pathogens, drug toxins and other chemicals, which must be eliminated or reduced to safe values to minimize their potential risk (BERGE et al., 2009). Thus, the composting of animals has be incorporated to prevent the transmission and spread of an infection (KALBASI et al., 2005) and to reduce the pathogenic microorganisms to appropriate levels (BERGE et al., 2009). Therefore, it is considered a resource that shows positive results on environmental and health aspects (SOTO et al., 2010). Thus, it is possible to assume that 
farms will have to incorporate the use of composters to directly and indirectly promote the health of the herd as a whole, affecting animal performance; therefore, in an improved sanitary condition and with less adversity, the dietary nutrients would be used primarily for the development of the animal and less for immune responses, thereby improving the FC.

With respect to the continuous variables initial weight and final weight, there was an increased DFI when the initial weight of pigs and the weight of the finisher pigs were higher (Table 3), similar to results obtained by Pierozan et al. (2016). In a comparison between light and heavy piglets at birth, Wolter et al. (2002) observed that, within any GF period, piglets who were heavy at birth had a higher daily weight gain and increased DFI that piglets who were lighter at birth. Thus, it was assumed that the animals entering the GF phases at a heavier weight also ended this phase with greater weight and consequently have a higher feed intake during the whole period of housing. Thus, there is a clear synergistic relationship in the initial and final weights with the DFI (SILVA, 2010).

The independent variables "initial weight" and "duration of the GF phases" influenced the dependent variable FC, which declined with an increasing initial weight of pigs and of the period in which the animals were kept on the farm (Table 5). Until reaching 56-63 kg, the pigs had an increasing lean meat deposition, and from this point forward, they were heavier and older, causing a decline in the FC because of a reduction in the deposition rate of lean tissue and an increase in fat deposition (BÜNZEN et al., 2014). Considering that the pigs enter the GF phases heavier when reaching their slaughter weight, seven days before then animals that enter lighter (WOLTER et al., 2002), batches with high initial weight spent more time than necessary in the farm until the lighter pigs reached slaughter weight, causing the FC to worsening for the batch as a whole. A possible explanation for the results of this study is that when animals are housed in GF units with a high average weight, a large number of pigs reach their slaughter weight earlier, but the lighter animals require more time to reach a slaughter weight, which is of interest to the company. The worsening of the FC for the entire batch is a result of an increased deposition of fat and less lean gain in animals with a higher initial weight.

The value of $44.4 \%$ of the total variance explained by the DFI model was close to that achieved by Pierozan et al. (2016) (50\%), but dissimilar to the value obtained by the Agostini et al. (2014) (62\%). For total variance explained by the FC model, $19.9 \%$ was observed in the present study, which was a closer value to that obtained by Agostini et al. (2014) $(24.8 \%)$ and distant from that observed by Pierozan et al. (2016) (64\%). All of these studies used a multiple linear regression model to quantify the factors that act on pig performance characteristics. The differences between the explained variance values could be attributed to differences between the variability of the factors included in the full models (final models with predictors).

The factor, "barn's position relative to the sun," had significance for both performance variables (DFI and FC), which could be explained because the factors included in each model were different (except the factor aforementioned), unlike the study by Pierozan et al. (2016) in which all the factors included in the linear regression models for DFI and FC were the same and were significant for both parameters.

\section{Conclusions}

Under the tested conditions, the multiple linear regression model for DFI was able to identify that there was an increased daily feed intake by pigs in the GF phases when the following conditions were met: I) the position of the barns in farm was opposite to the direction of sunrise-sunset (daily feed intake $0.9 \%$ higher); II) the initial weight of the animals of the batch was greater; and III) the final weight 
of the animals in the batch was greater. The model obtained for FC identified improvement in this index when the following conditions were met: I) the farms had humidifiers/misting in their installations (FC $0.7 \%$ better); II) the farms had composter facility on the farm (1.2\%); and III) the farm had trees planted around the barn of pigs $(0.7 \%)$. The FC worsened under the following conditions: I) the position of the barns at the farm was opposite to the direction of sunrise-sunset (FC 1.2\% worse); II) the initial weight of the animals in the batch was greater; and III) the animals spent more days on the farm before they could be transported to slaughter. These results can contribute to the improvement of the indices evaluated by actions on the factors involved, and this mathematical feature is a tool to support technical decisions on the farm.

\section{Acknowledgements}

First, we thank the cooperative participants, who trusted us with the data from their farms. We also thank the public research project funded by the Spanish Ministry of Education (AGL 2011-29960), in which this study was developed.

\section{Referências}

AGOSTINI, P. S.; FAHEY, A. G.; MANZANILLA, E. G.; O'DOHERTY, J. V.; BLAS, C.; GASA, J. Management factors affecting mortality, feed intake and feed conversion ratio of grow-finishing pigs. Animal, Cambridge, v. 8, n. 8, p. 1312-1318, 2014.

ASSOCIAÇÃO BRASILEIRA DOS CRIADORES DE SUÍNOS - ABCS. Panorama Setorial da Suinocultura. Dossiê detalhado do setor suinícola. [S.1.]: Sede Brasília, 2015. Disponível em: <https://issuu.com/revistaabcs/ docs/panorama_setorial>. Acesso em: 30 ago. 2016.

BANHAZI, T. M.; SEEDORF, J.; RUTLEY, D. L.; PITCHFORD, W. S. identification of risk factors for suboptimal house conditions in Australian Piggeries: Part 3. Environmental Parameters Journal of Agricultural Safety and Health, St. Joseph, v. 14, n. 1, p. 41-52, 2008.

BERGE, A. C. B.; GRANVILLE, T. D.; MILLNER, P. D.; KLINGBORG, D. J. Methods and microbial risks associated with composting of animal carcasses in the United States. Journal of the American Veterinary Medical Association, Ithaca, v. 234, n. 1, p. 47-56, 2009.

BERTON, M. P.; DOURADO, R. C.; LIMA, F. B. F.; RODRIGUES, A. B. B.; FERRARI, F. B.; VIEIRA, L. D. C.; SOUZA, P. A.; BORBA, H. Growing-finishing performance and carcass yield of pigs reared in a climatecontrolled and uncontrolled environment. International Journal of Biometeorology, Nova Iorque, v. 59, n. 8, p. 955-960, 2015.

BÜNZEN, S.; APOLÔNIO, L. R.; SILVA, M. A. Técnicas de manejo e alimentação para melhoria da conversão alimentar. In: FERREIRA, A.H.; CARRARO, B.; DALLANORA, D.; MACHADO, G.; MACHADO, I. P.; PINHEIRO, R.; ROHR, S. (Org.). Criação de suínos: teoria e prática. Brasília: ABCS, Integrall, 2014. p. 686-697.

CHOI, H. L.; SONG, J. I.; LEE, J. H.; ALBRIGHT, L. D. Comparison of natural and forced ventilation systems in nursery pig houses. Applied Engineering in Agriculture, St. Joseph, v. 26, n. 6, p. 1023-1033, 2010.

COLLIN, A.; VAN MILGEN, J.; DUBOIS, S.; NOBLET, J. Effect of high temperature on feeding behaviour and heat production in group-housed young pig. The British Journal of Nutrition, Cambridge, v. 86, n. 1, p. 63-70, 2001.

DAGA, J.; CAMPOS, A. T.; FEIDEN, A.; KLOSOWSKI, E. S.; CÂMARA, R. Análise da adequação ambiental e manejo dos dejetos de instalações para suinocultura em propriedades na região oeste do Paraná. Engenharia Agrícola, Botucatu, v. 27, n. 3, p. 1-11, 2008.

DIAS, A. C.; CARRARO, B. Z.; DALLANORA, D.; COSE, F. J.; MACHADO, G. S.; MACHADO, I. P.; PINHEIRO, R.; ROHR, S. A. Manual brasileiro de boas práticas agropecuárias na produção de suínos. Brasília: ABCS, 2011. 140 p.

DOUGLAS, S. L.; SZYSZKA, O.; STODDART, K.; EDWARDS, S. A.; KYRIAZAKIS, I. Animal and management factors influencing grower and finisher pig performance and efficiency in European systems: a metaanalysis. Animal, Cambridge, v. 9, n. 7, p. 1210-1220, 2015.

GIBON, A.; SIBBALD, A. R.; THOMAS, C. Improved sustainability in livestock systems, a challenge for animal production science - Introduction. Livestock Production Science, Amsterdam, n. 61, p. 107-110, 1999.

HECK, A. Fatores que influenciam o desenvolvimento dos leitões na recria e terminação. Acta Scientiae Veterinariae, Porto Alegre, v. 37, p. 211-218, 2009. Suplemento 1. 
KALBASI, A.; MUKHTAR, S.; HAWKINS, S. E.; AUVERMANN, B. W. Carcass composting for management of farm mortalities: a review. Compost Science \& Utilization, Emmaus, v. 13, n. 3, p. 180-193, 2005.

KIEFER, C.; MEIGNEN, B. C. G.; SANCHES, J. F.; CARRIJO, A. S. Resposta de suínos em crescimento mantidos em diferentes temperaturas. Archivos de Zootecnia, Córdoba, v. 58, n. 221, p. 55-64, 2009.

MAES, D.; DUCHATEAU, L.; LARRIESTRA, A. J.; DEEN, J.; MORRISON, R. B. Risk factors for mortality in grow-finishing pigs in Belgium. Journal of Veterinary Medicine B, Berlin, v. 51, n. 7, p. 321-326, 2004.

MANNO, M. C.; OLIVEIRA, R. F. M.; DONZELE, J. L.; OLIVEIRA, W. P.; VAZ, R. G. M. V.; SILVA, B. A. N.; SARAIVA, E. P.; LIMA, K. R. S. Efeitos da temperatura ambiente sobre o desempenho de suínos dos 30 aos 60 kg. Revista Brasileira de Zootecnia, Viçosa, MG, v. 35, n. 2, p. 471-477, 2006.

MILlER, T. G. Swine feed efficiency: influence of temperature. [S.1.]: IPIC, 2012. 2 p. Available at: $<$ http://lib.dr.iastate.edu/cgi/viewcontent. cgi? article $=1005 \&$ context $=$ ipic factsheets $>$. Accessed at: 30 ago. 2016.

NÄÄS, I. A.; JUSTINO, E. Sistemas de climatização parcial e total em granjas de suínos. In: FERREIRA, A. H.; CARRARO, B.; DALLANORA, D.; MACHADO, G.; MACHADO, I. P.; PINHEIRO, R.; ROHR, S. (Org.). Criação de suínos: teoria e prática. Brasília: ABCS, Integrall, 2014. p. 896-905.

OLIVEIRA, J.; GUITIÁN, F. J.; YUS, E. Effect of introducing piglets from farrow to finish breeding farms into all-in all-out fattening batches in Spain on productive parameters and economic profit. Preventive Veterinary Medicine, Amsterdam, v. 80, n. 4, p. 243-256, 2007.

PIEROZAN, C. R.; AGOSTINI, P. S.; GASA, J.; NOVAIS, A. K.; DIAS, C. P.; SANTOS, R. K. S.; PEREIRA JÚNIOR, M.; NAGI, J. G.; ALVEZ, J. B.; SILVA, C. A. Factors affecting the daily feed intake and feed conversion ratio of pigs in grow-finishing units: the case of a company. Porcine Health Management, Barcelona, v. 2, n. 1, p. 1-8, 2016.
POMAR, C. The utilization of mathematical models to improve swine production. In: CONGRESSO LATINOAMERICANO DE NUTRIÇÃO ANIMAL, 6., 2014, Estância de São Pedro. Anais... Estância de São Pedro: [s.n.], 2014. p. 23-26.

RENAUDEAU, D.; GOURDINE, J. L.; ST-PIERRE, N. R. A meta-analysis of the effects of high ambient temperature on growth performance of growing-finishing pigs. Journal of Animal Science, Champaign, v. 89, n. 7, p. 2220-2230, 2011.

SILVA, C. A. Consumo dos suínos. In: VIEIRA, S. L. (Org.). Consumo e preferência alimentar dos animais domésticos. Londrina: Midiograf, 2010. v. 1, p. 204-265.

SOTO, F. R. M.; COELHO, C. P.; BENITES, N. R.; BONAMIN, L. V.; MELVILLE, P. A. Elimination of Escherichio coli from piglet carcass using an on-farm composting system. Veterinary Record, London, v. 166, n. 18 , p. $564-565,2010$.

TEDESCHI, L. O.; FOX, D. G.; SAINZ，R. D.; BARIONI, L. G.; MEDEIROS, S. R.; BOIN, C. Mathematical models in ruminant nutrition. Scientia Agricola, Piracicaba, v. 62, n. 1, p. 76-97, 2005.

VAN HEUGTEN, E. Growing-finishing swine nutrient recommendations and feeding management. In: MEISINGER, D. J. (Ed.). National swine nutrition guide. Ames: Iowa State University Press, 2010. p. 80-95.

VILLALBA MATA, D. V. Construcción y utilización de un modelo estocástico para la simulación de estrategias de manejo invernal en rebaños de vacas nodrizas. 2000. Tesis (Doctoral en Ciencia y Tecnologia Agraria i Alimentaria) - Departament de Producció Animal. Universitat de Lleida, Lleida.

WOLTER, B. F.; ELLIS, M.; CORRIGAN, B. P.; DeDECKER, J. M. The effect of birth weight and feeding of supplemental milk replacer to piglets during lactation on preweaning and postweaning growth performance and carcass characteristics. Journal of Animal Science, Champaign, v. 80, n. 2, p. 301-308, 2002. 
